\title{
LIVING WITH REINDEER THIRTY YEARS AFTER SOCIALISM: LAND USE AND LARGE REINDEER HERDING AMONG THE EVENKI OF SOUTHEAST SIBERIA*
}

\author{
DONATAS BRANDIŠAUSKAS \\ Professor of Anthropology \\ Institute of Asian and Transcultural Studies \\ Vilnius University \\ Universiteto St. 5, LT-01513 Vilnius, Lithuania \\ e-mail: donatas.brandisauskas@if.vu.lt
}

\begin{abstract}
30 years after socialism many groups of Evenki reindeer herders failed to survive in the suboreal taiga of East Siberia. By making reference to two case studies from the northern part of the Zabaikal region and southern part of the Republic of Sakha, this article shows how the successful continuation of reindeer herding is based on the ability of charismatic leaders mobilising Evenki communities around reindeer herding and subsistence economies. This success also relies on connection to different agents of power in local administrations, large cities and governments and the use of all of the available opportunities that infrastructure or economic agents can offer.
\end{abstract}

KEYWORDS: Siberia • reindeer herding • Zabaikal Region • South Yakutia • Evenki • land use strategies

\section{IN T RODUCTION}

Over the last five years several Evenki clan communities (rodovyye obshchiny) in East Siberia, owning between 40 and 300 reindeer, respectively, just ceased to exist. These extended families lost all their reindeer and neglected large taiga territories of their subsistence in various parts of Buryatia Republic, Zabaikal Region, South Sakha Republic and Khabarovsk Region. These groups relied on an independent, autonomous lifestyle and lived with reindeer in taiga areas located far from industrial centres. These interstitial practices were seen as the groups maintaining their dedication to reindeer herding, which relied on individual skills and a maintenance of personal/cultural preferences to

* This research was supported by the Research Council of Lithuania (No. S-MIP-17-3). Field research and dissemination was supported by SSRHC grant 435-2016-0702, NORRUS grant 257644/H30. 
continue a nomadic way of life. In his overview article of two Evenki reindeer herding groups, David Anderson (2006a) observed that reindeer herders who used this interstitial practice managed to survive after the demise of collective farms because of their flexibility and ability to adapt to the new conditions of post-Soviet life. A good example of this is the Boiun reindeer herding community from the Zabaikal Region that consciously lived in remote and hardly accessible taiga places. Their herds reached up to 500 reindeer even though they were only linked to the outside world to obtain food. They refused to use anything that was based on gasoline or required cash (see Anderson 2006b; 2012). During my fieldwork in Tungokochen County in Zabaikal Region between 2004 and 2012, the extended family of Aruneyev-Zhumaneyev mainly relied on their taiga knowledge and hunting skills. Only occasionally did they use outside resources to meet their subsistence needs (Brandišauskas 2017a). Hunting for fur was the main source of money for families who had no possibility to hire other herders. Thus they had family-level subsistence income with little reliance on outside sources. (Ibid.)

This type of relationship between nomadic Evenki and the land, animals, spirits and people is quite similar to the pre-Soviet economy. This mainly relied on negotiation between different taiga agents and sometimes villagers, rather than relying on urban or state actors. This type of nomadic economy Anderson (2006a: 100) aptly described as a "certain type of opportunistic reindeer herding" that also showed for him all the necessary features of sustainability. However, almost 25 years after the collapse of collective farms it appeared that by using a strategy to maintain their autonomy and minimise connections with market economies and the local government administration for support that would help them maintain land access rights, most reindeer herding enterprises had ceased to exist.

For many clan communities, such as Boiun, it became impossible to manage reindeer herding in the taiga environment when land use had become more and more regulated and constrained by different state agents and industrials enterprises. Furthermore, most former reindeer herders point to the prohibition of the poison Barium Ftorotsetat, which had been a crucial means of exterminating wolves for more than half century. ${ }^{1}$ With a post-Soviet collapse of collective farm infrastructure, the number of wolves and bears increased dramatically, threatening not only live stock but also humans, causing tragic outcomes for many reindeer herding communities all over East Siberia. Furthermore, the failure to ensure or maintain land use access rights for reindeer herding and even hunting soon turned into long term tension between clan communities on the one hand and administration or village-based hunters working for local entrepreneurs as well as resource extractors on the other hand. In this context, reindeer herding became impossible without generating all kinds of effort from diverse sources. Herders had to tap into social, economic and cultural capital that involved networks of indigenous communities, villages and the district administration. Furthermore, it became impossible to ensure the wellbeing of the community without ensuring reciprocal exchange relations or tensions with a variety of state agents as well as representatives of industry, land and resource extractors, and trade markets.

In this article, I would like to describe how two different reindeer herding communities managed to survive chaotic post-Soviet privatisations, the drop in the reindeer population, negotiations over land rights, and the recent and rapid penetration 
of industry into the Zabaikal and Sakha Republic regions of the taiga. The research is based on long-term fieldwork that I have conducted with different Evenki communities in the Zabaikal Region, Amur region, Sakha Republic and Buryatia Republic since 2004. In 2016-2017 I had the opportunity to conduct fieldwork in different taiga and village settings with various Evenki leaders, members of their families, and also artists, craftsman, teachers, elders, village youths, and taiga hunters and reindeer herders living in taiga camps or log cabins.

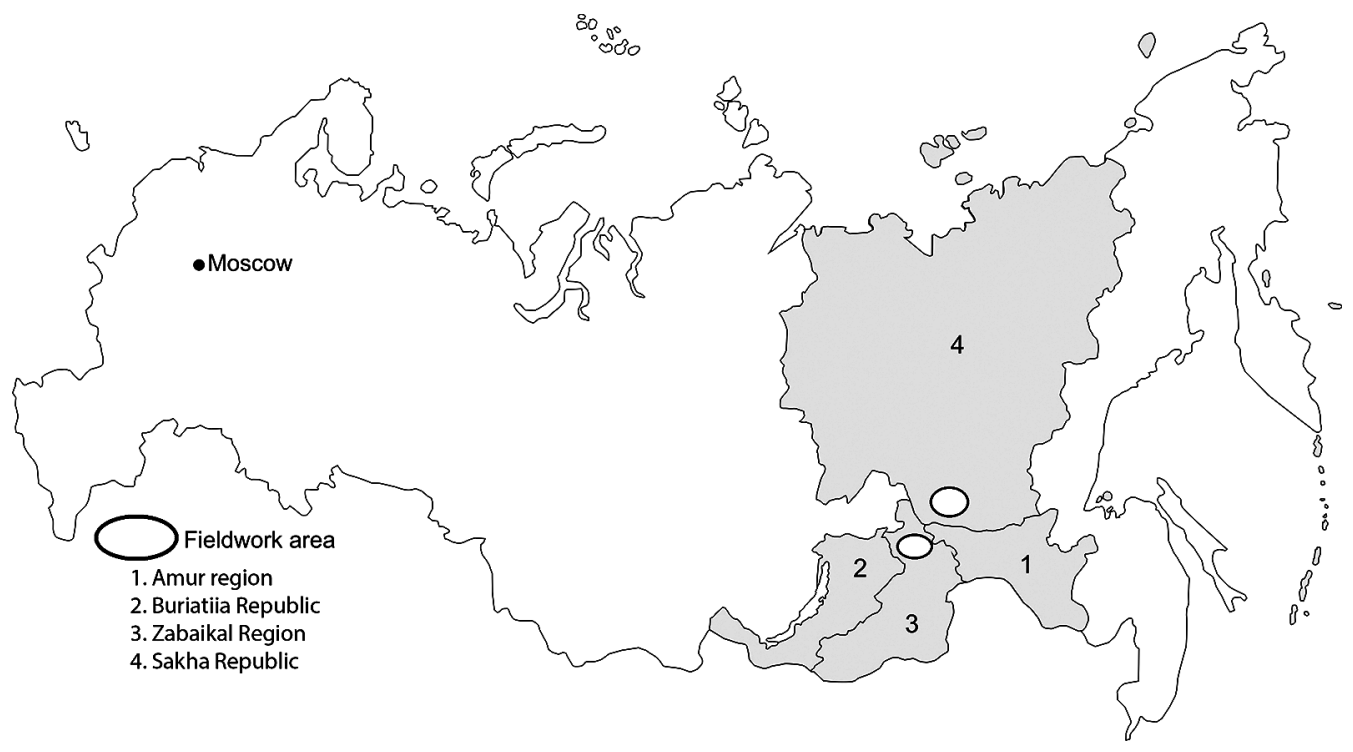

Figure 1. Map of the field research area created by Viktoriia Filipova and Donatas Brandišauskas.

The successful Tyanya clan community (Sakha Republic) owns a large reindeer herd of up to 1,600 reindeer. It can remind one of Caroline Humphrey's (1999: 78) description of the Soviet collective farm as a "total social institution". Economic life is combined with social and cultural functions. Reindeer herding has a specific socio-political status and a national level political representation, while at the local level it is a whole community with its own corporate identity associated with herding. The Tyanya community is also the administrator of reindeer herding in the village, providing strict guidance. Herders are motivated by salaries and rewards to accomplish the work plans proffered by clan community leaders. Furthermore, the community, in corpora, is also able to negotiate benefits from the resource extraction industry as well as defend their interests at different levels of the political arena. The Gevan clan community (Zabaikal Republik) is a successful reindeer herding community with 2,000 reindeer. It is constituted of a group of close-knit relatives who are involved in managing the reindeer. Such community management also involves the use of the village as a stable base for the reindeer herders. They also use opportunities that the Baikal Amur Magistrail (BAM) railroad makes available as an elaborate infrastructure element for the movement and transportation of different gear and trading items. The railroad provides exceptional opportunities for economic transactions and mobility. 
As both of my examples demonstrate, indigenous mastery of the land is inseparable from being able to make taiga liveable for both humans and animals and protecting it from poachers, predators and miners. Furthermore, this mastery can also be sustained through constant logistical movements by river boats, animals, snowmobiles, caterpillar vehicles or trains when transporting goods, furs, hunted carcasses or camping supplies between taiga and villages (see, for creative mobility, Davydov 2018). At the same time reindeer herding became a crucial activity for most of the Evenki clan communities as a cultural means of maintaining communal indigenous identity expressed through public festivals, rituals and races. Reindeer herding also became important economic capital ensuring support for past, present and future generations. As symbolic and social capital, reindeer herding serves to remind the state of its moral obligations to the indigenous people and their cultural and economic peculiarities. Agents of industry must also recognise reindeer herding as a moral symbol of an indigenous way of life for small numbered ethnic groups that they potentially endanger. In this context, reindeer can easily be transformed from cargo animal to strategic means of asserting the traditional rights of the community. In so doing reindeer not only link people to local and distant lands, but also ensure access rights, although these provisions often entail complicated negotiations with various agents.

\section{CASE 1: THE EVENKI TYANYA VILLAGE AND REINDEER HERDING IN OLEKMA DISTRICTS (SAKHA REPUBLIC)}

The head of Tyanya village, Arsentiy Nikolayev, is the main person you will meet if you visit this remote village (Photo 1). Tyanya has a population of about 500, most of whom reside in the 170 plus houses. The village is located about $280 \mathrm{~km}$ from the district centre of Olekminsk, and both are situated in the southern part of the Republic of Sakha. Geographically the village is located in the suboreal mountainous taiga and is generally reached by boat. To get there one travels through numerous interconnecting rivers, such as the Lena, Olekma, Chara, Tokko and Tyanya, all the time going upstream to the remotest part of Olekma district. However, there is always a chance to take one of the occasional planes that connect small and remote villages in Olekma district. During the winter, especially the three months after the New Year, flying is the easiest way to reach the village.

Arsentiy was twice elected head of village administration and also served as leader of the Association of Olekma District Indigenous People, as well as serving as an advisor to the President of the Sakha Republic. Furthermore, his extended family runs the Tyanya indigenous clan community, which oversees the use the large territory required for traditional subsistence practices (i.e. herding and hunting). The community is one of the first indigenous economic units established in Yakutia (see Belyanskaya 2013: 169). Any visit by an outsider with a formal interest in the community must be carefully planned in advance with Arsentiy, one will not be able to move freely without his consent.

In 2016 I met Arsentiy for the first time, who met me with a stunning look from his piercing eyes. He peppered me with questions intended to uncover whether or not I had any hidden political agenda in my research. He was curious about what would 


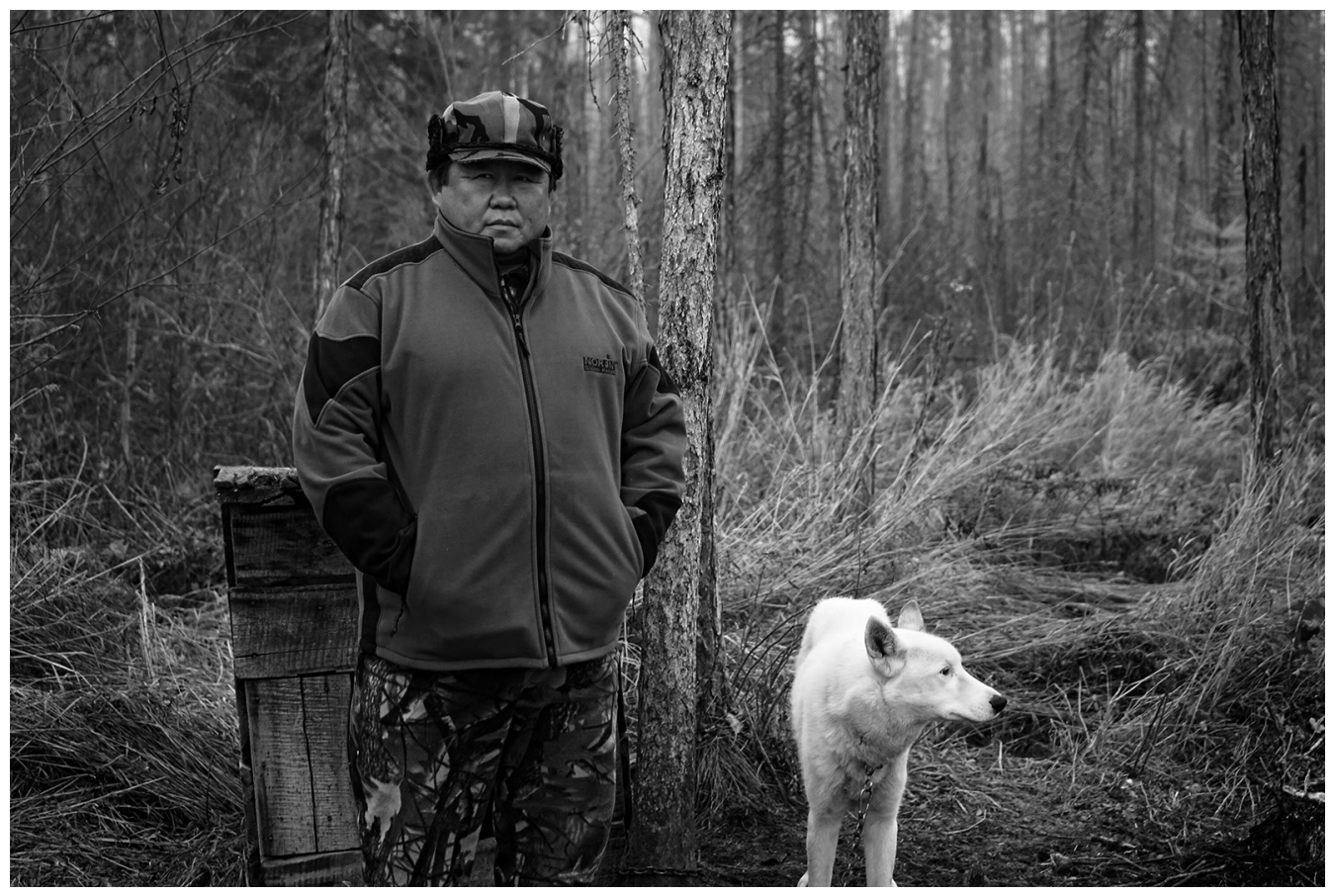

Photo 1. Arsentiy Nikolayev in his dog/wolf interbreeding farm. Photo by the author.

interest a foreign scientists from the rival country of Lithuania? Secondarily he also wanted to find out how my academic work could be of benefit to the indigenous people he represented. Although he challenged me with questions in the small hotel in Olekma city, after I passed his examination he put all his efforts behind me in order that I could have the best access to the remote villages in the region. Whether in a village or city, Arsentiy travels in the clan-community-owned black Patriot driven by his relative. $\mathrm{He}$ also rides a large ATV motorcycle when inspecting different parts of Tyanya village. Indeed, it is obvious that his authority is well felt in every corner of the village even when he is absent. This means that village life is well-structured by his organisational efforts.

Arsentiy comes from a prominent family of reindeer herders that were well recognised during the Soviet period. Family members were either prosperous brigade members of different reindeer herds, skilled craftsman and hunters, or even well-respected wolf hunters. Despite being a reindeer herder, his father was also involved in traditional dances in which shamans were enacted on stage during the Soviet period. This gave him some influence after the collapse of the Soviet Union when shamanic knowledge became officially valued and important. Furthermore, his family maintained a ritual bundle of decorated idols called Barylakh, which for the Evenki have a powerful agency that when properly worshipped, generate luck, prosperity and wellbeing for the family. Indeed, both the village and the Tyanya community, the leaders of which come from Arsentiy's kin, can be considered prosperous and flourishing. 
The Tyanya village is famous in South Sakha as the most resilient reindeer herding community in the region. The Tyanya clan community owns four reindeer herds, given to the community on long-term lease by the state, that migrate for grazing to different parts of the mountainous territory. Immediately after the collapse of the Soviet Union, Arsentiy's extended family received an allotment of reindeer when the collective farm was privatised. In the 1990s the family had 120 reindeer, in 2000 the 900 reindeer. Today the clan community claims ownership of more than 2,000 reindeer. $^{2}$ Over the last few decades the community acquired reindeer from various communities dispersed throughout East Siberia in Aldan (Khatastyr), the Amur region (Ust' Nyukzha), the Irkustk region (Perevoz), and Zabaikal'ia (Chapo Ologo) and even Ust' Maya (central Yakutia), making theirs one of the largest herds in the whole suboreal region of East Siberia. Trade was important for interbreeding reindeer with the purpose of "enhancing the animal's blood" and "adaptive qualities" (FM: 2017). It was also important for the community to have a large number of reindeer in order to master formally the large grazing territory and other subsistence economies such as hunting. While villagers still rely on fur animals (sable) for cash as well as game animals (moose, wild reindeer, elk, roe deer) for food, reindeer are actively used during the winter season to transport cargo and for riding. Despite the increasing importance of the snowmobile for travel, the value of reindeer remains unchallenged. More important, reindeer are also used as an important marker of identity. One of the most important events for indigenous communities in the Sakha Republic is reindeer herder's day, with reindeer races, food, and lots of celebratory activities marking Evenki identity. Many other cultural practices revolve around reindeer including the production of footwear and gear for commercial sale, maintaining social relations between Evenki communities, and even finding brides. New trends have been initiated by the local state development system. The clan community has plans to develop and promote cultural tourism showing Evenki culture on stage and selling material cultural products. Some reindeer are slaughtered for meat with three tons per year sold to a nearby gold mine run by Neryungri Metallic. Dried antlers and other reindeer products are sold to Chines merchants. Last but not least the clan community also receives a stable income through state subsidies (subsidii) linked to the number of reindeer owned. Such incomes can be used as a regular salary. About $80 \%$ of the expenses for the gear used in reindeer herding are refunded by the state (Sakha Republic). This includes oil for the generator, satellite phones, saws, canvas, GPS solar panels, and batteries.

As a person who has been doing intensive fieldwork in different Evenki communities over the last decade, I was surprised at the apparent wealth I saw along the Tyanya river, were nearly all boats possessed powerful, new Yamaha engines. The village showed signs of a sustainable existence: it had a new school full of children; there were neat gardens; there was a modern hospital with an annexed dispensary, two sawmills, a gasoline station, and a new administration building. In 2016, it was not as easy to make contact with people when walking around in the villages of Zabaikal County or Amur region. However, there were no difficulties meeting with aggressive and unleashed hunting dogs, just as in earlier times. Furthermore, I did not see anybody who was drunk or any instances of public quarrelling as was usual in earlier times. The village moved to the prohibition of alcohol in the 1980s and now only a small amount of alcohol (mainly beer) can be bought in one of the two village stores on special occasions 
such as an elder's birthday. Young hunters told me that it is no longer fashionable (ne modno) to drink or even smoke; and, indeed it seemed as if fewer people were smoking than before. In the Olekminsk centre, after agreeing with Arsentiy on the logistics of our trip to Tyanya, I was already strictly told by him not to take any alcohol to the reindeer camp. "I will find out anyway if you do so," he said (FM: 2016). And indeed, as we found out later, Arsentiy knew about anything that happened in the village and taiga camps, as well as in the remote herding areas.

Indeed, Arsentiy is a very charismatic administrator as well as a skilful clan community manager. In addition to traditional practices as well as reindeer herding and hunting wild game, the clan community also runs a building business and participates in local auctions. The community is involved in road building, construction and subcontract work. Every morning and evening Arsentiy keeps in touch with reindeer brigades by radio. Reindeer herders say that his advice is always valuable and works well, and therefore he is called "radio reindeer herder" (FM: 2016). Indeed, Arsentiy spent his childhood and much of his youth with his relatives and parents in reindeer herding camps learning both hunting and herding skills.

Arsentiy and his relatives follow the movement of the people involved in the administration and clan community. Their movement and the attention they give to who is doing what in the territory plays an important role in mastering the territory as an economic, political and social unit that interconnects people via networks of boats, reindeer, all-terrain vehicles and foot travel. Any movement is combined with multiple supply tasks as well as daily economic activities such as hunting or fishing. Even though it is a remote area the result of this well-organised communication network is that people always arrive punctually even though it takes a few days or weeks to travel via roadless taiga walking or riding reindeer. It is obvious that all taiga networks and infrastructure function extremely well in part because the leaders are interconnected via family ties and long-standing friendships. The main merit of Arsentiy is his constant effort to maintain the village infrastructure including education institutions; under him a gasoline station was recently established to be used for village needs. In addition, most hunters started to build wooden house in their hunting territories based on allocations given by the clan community.

The number of reindeer varies from year to year, but the largest single herd (there are as mentioned four herds all together) owned by the community has 500 reindeer. This number is optimal in terms of looking after the animals in the mountainous taiga environment. Chief herder Andrey Nikolayev, a cousin of Arsentiy, is also a very experienced reindeer herder who is in charge of counting reindeer twice a year, after New Year and in June. He also serves as a private driver for Arsentiy in cities. He is in charge of buying all the reindeer and organising the transportation of reindeer to the community. The entire reindeer herd owned by the clan community is divided into four brigades; each has its own brigadier, territory for herding and specific ear mark designating the brigade. Arsentiy's other cousin also serves as brigadier in one of the reindeer herding groups. Year after year herders change their migration with the herd, sometimes reaching territories located on Kindigir nasleg (Olekma ulus, Sakha Republic), or the Zabaikal or Irkustk regions. Usually, each herd moves between camps over a stretch of 50 kilometres, however, every few years the area for grazing can be changed (Davydov 2014). When people move to a new camp they will ride the reindeer and load their belongings onto 'cargo' reindeer or sleds pulled by them. 
Every brigade consists of five to eight people. Among these male herders are one or two females who are employed to cook, called chum workers. During the calving and mating seasons in spring and autumn respectively the camp size swells with additional workers who build corrals and take care of the new-born calves. Every brigade lives in self-made canvass tents equipped with an iron stove as well as 4 or 5 hunting rifles. A separate tent can be used exceptionally as a warm space for personal hygiene and washing. There can be up to ten well-trained hunting dogs in camps. Most reindeer herders have their own reindeer. The herd may include privately owned reindeer belonging to villagers who will help out by building corrals or with other jobs. If a hunter manages to kill a wolf, then Arsentiy awards him with a valuable female reindeer; if a bear, then he receives an adult male reindeer. If the year is successful and around two thirds of new-born reindeer survive, then reindeer herders will feel confident and happy when observing the new additions to their herd. In addition, monthly salaries are paid to herders by the community, while food, clothing and gasoline are received from gold mines as compensation. Domestic reindeer provide a stable cash income to the clan community, providing as much as $80 \%$ of expenses on gear and transportation spent for reindeer herding needs. Salaries (10,000-15,000 roubles per month, 150-200 USD) are also paid to reindeer herders by the clan community. Hunting fur animals in winter also brings cash incomes for most male based in villages and taiga. Often community allows hunters to use a cargo reindeer in the winter season, while all hunters' fur is traded by clan community leaders in auctions.

Clan community hunters also receive the required equipment and food needed for the winter on credit. In turn they supply the community with sable fur that is later traded at Siberian auctions. Fur animal hunting is the most important source of cash for most male hunters involved in this subsistence economy, while employment in public institutions also provides a stable income for most female villagers. Every hunting plot used by the family has in most cases been inherited by individual hunters from their fathers, who hunted there in Soviet period, or even grandfathers, who dwelled there with their reindeers. Often people used to refer to clan territories linked to the certain rivers or certain parts of rivers as places of birth or for burying their parents or grandparents. Hunting plots are usually reached by the network of rivers. Most camps and $\log$ cabins are equipped with oil generators or solar panels to generate electricity, meaning that people are able to have an electric light in the tent or house, charge their smartphones, and use laptops for entertainment.

Most of the men are involved in hunting game animals such as moose, wild reindeer, elk, and water fowl almost all year. Most children spend their holidays together with their parents hunting or fishing in their territories enabling children as young as ten to boast about hunting large game animals. Fishing for river fish such as taimen (Hucho taimen), lenok (Brachymystax), sig (Coregonus), nel'ma (Stenodus leucichthys nelma) and picking berries such as lingonberries and blueberries are also important activities used to supplement the winter diet. Fishing and picking berries are activities that all members of a family participate in. These activities are of growing economic importance since both fish and berries are desired by and traded to merchants from Olekminsk city. In autumn, every family travels by boat to their hunting areas where they fish and spend a month collecting food and other resources for winter. Hunting is conducted only in the family's allotted hunting plot, but one can fish anywhere. The only rule is to avoid putting nets 
in places where someone else is already fishing with nets. Every family needs up to two large barrels of salted fish per year. Villagers go wild animal hunting in their own winter hunting territories. Arsentiy told me that "If you feel that you are in charge of a hunting place, then you protect it and never kill more than you needs in order to maintain a good balance of animals in the area" (FM: 2016). At the same time, according to Evenki ethics if one sees an animal crossing a river on your boat route, you can hunt it. One is allowed to take any opportunity offered by the taiga. As a result, every ten or twenty kilometres one will find a log house or camps with canvas tents along a river where people have settled to fish or hunt. In such places people also keep their gasoline supplies in case anybody travelling by boat runs short and needs to borrow some. The only obligation is to inform the owner and repay it as soon as one visits the village.

It is interesting to see how people in reindeer herding camps are skilful in generating, adjusting and reusing everything that is traded, found or harvested from neglected buildings or discarded equipment from geological expeditions or abandoned mines. Pipes from mines are cut and used for reindeer sleds, and if herders need anything like a nail or piece of wire they visit these abandoned places to harvest what is needed. Valuable equipment such as snares, reindeer lassos, saddles, birch bark containers, knives, tents, iron stoves, sleds, corrals, elevated storage platforms and winter footwear are produced by skilful reindeer herders in the camps (Brandišauskas 2018). Living in the taiga is a constant process of accommodating all available resources in order to meet one's needs, whether it comes from old geological building, neglected mines, cordons or dry sites suitable for camps and corrals. Previous infrastructure such as cut lines, roads and especially neglected buildings are viewed as places to store goods, or herders may modify these ruins for other purposes (see Brandišauskas 2017b; Davydov 2018). Using all the available resources scattered in the taiga is a continuation of the intuitive means by which people master large territories. As in the pre-Soviet period these movements are always linked to 'catching opportunities'. These opportunities are a mixed bag and require intuitive capacities to recognise the affordances that, to Western eyes, would appear to be ruins or waste material. These affordances can range from the movements of boats and ATVs to the movement of shift work across the seasons, to elections and holidays.

Two all-terrain caterpillar vehicles, MTLB, belong to the clan community. The clan community also owns a base camp near the confluence of the Chukakh and Tokko rivers. This camp contains a recently built log house used for sleeping and cooking, and a sauna; there are also storage houses and a sawmill. In winter, clan community hunters used the base camp to take saunas and for storage and picking up supplies. During the winter seasons dogs and sometimes horses are kept at the base camp and used for hunting. Indeed, the use of dogs also allows Arsentiy to accomplish his dream of interbreeding dogs with wolves and, as he tells me, the results have been good. In the dog stall at the base camp there are over 20 dogs with wolf blood that are expected to be better hunters than normal dogs. These cross-breeds are carefully selected and looked over and some puppies are given to close friends and relatives as prized gifts. For the most part, however, they are used for hunting by clan community hunters. The good dogs are very highly valued in this part of the Siberia because most sable is hunted by tracking them with dogs. The base house in Chukakh also serves as an area where all visiting officials, friends and researchers are comfortably accommodated and hosted. 
Therefore, this place is colloquially referred to as fazenda, the local phonetic translation of the Spanish term hacienda. In Russia, South American soap operas are very popular and fazenda refers to a prosperous mansion with a large land holding.

The sharing economy is one the most vivid characteristics of the village. It remains a moral obligation that hunted animals should be shared among relatives and friends, while people also share salted fish if someone runs out during the winter. Hence, as elder female hunter and former reindeer herder Rozalina told me once, when her son brought home the carcasses of eight wild reindeer and a visiting teacher told her that he must be happy to have a long-term meat supply, it was also obvious to the teacher that all the meat would soon be gone since it would be shared among neighbours and relatives (FM: 2016). Indeed, hunters even joked that as soon as villagers see loaded boats coming to the village, family members will send their children with a tin bowl expecting a share of the meat. People say that though hunting is regulated, nevertheless, people see it as a birth right, saying "we cannot live without meat because we are Evenki".

Most villagers believe that maintenance of close-knit relations and a well-kept infrastructure ensure that public work continues in the village and that this work is most important for sustaining the village. The most important cash income comes from state institution salaries, pensions, and financial support for children. The clan communities also provide employment for those who lack it, or benefits from the state. Arsentiy believes that due to the healthy life and success of the village, many of the young adults return after their education in Yakutsk (FM: 2016). Many people acknowledge that hunting and fishing, as well as the peaceful village life, brings a sense of self-sufficiency and simplicity that is the opposite of the complicated life found in cities.

Arsentiy believes that every Evenki must do what he or she knows best, referring to taiga subsistence (promysel). He adds, "I do not respect those who do just any kind of job". (FM: 2016) He seems to be referring here to those who decide to work in the gold mines. Arsentiy himself explains his role in the following way: "I push people hard, but people see that I know what I'm doing and have the ability to accomplish tasks, therefore they have respect [for me]." Some people refer to him as a bear and indeed Arsentiy says that the bear is closely related to his personality (and therefore it is strictly prohibited for him to hunt a bear). When other people dream about a bear it means that Arsentiy is going to appear. Indeed, one can find a close analogy in the Evenki cosmological idea of the bear, which is understood to be master of the taiga while Arsentiy is master of this Evenki village. Arsentiy's cosmological power is strengthened because he says to other people, "when I die, you should not misuse what I have left, since I will be watching over you". (FM: 2016)

The success of reindeer herding and subsistence economy is not only strengthened by merging administration power with clan community management, but also by the efforts and successes in dealing with organised crime in the area. Many businessmen say that until recent years many economic activities and territories in Siberia and especially in the BAM region controlled by gang units called blatnyye. Locally, mafia type organisations were also referred to as smotryashchiye ('the one who is looking after'). Businessmen had to pay tribute to the smotryashchiye, who guaranteed a peaceful existence as well as providing support called krysha ('roof'). With the advent of a successful economy in Tyanya, the smotryashchiye also made attempts to collect tributes, however they were unsuccessful after a meeting between well-armed Tyanya village hunters 
and so-called bandits. The bandits understood that it was impossible to collect tribute in places that are quite difficult to access except by plane or by boat because this access causes unexpected challenges for people who are inexperienced in water navigation and the taiga landscape. As one hunter explained to me: "We are the most resistant community and it is not an easy task to interfere with our lives because we are like one clan" (FM: 2016).

Many villagers rely on Arsentiy's organisational abilities and respect him as the head of administration, but what is more important to them is that he negotiates skilfully with the resource extraction industries. When Nord Gold at OOO Neryungri Metallic started to mine gold in Temnyi-Tabornyi in 2000, Arsentiy made continuous attempts to receive some benefits for the village clan community. Such compensation for local communities relies neither on legal rights to these resources nor any form of begging. It was more complicated, as village elders believed that mining companies always try to apply a combination of strategies to deal with community leaders, such as persuasion, intimidation, and finally confrontation via accusations of corruption or other legal means. Arsentiy himself had to deal with different challenges, such as accusations of taking compensations illegally. He was also accused of exploiting reindeer herders and therefore had to defend himself at many different state institutions. In many cases his position as advisor to the President of the Sakha Republic on indigenous issues helped him maintain a position of equal power with his accusers. (FM: 2016)

If Evenki used to feel that the gold mine companies failed to maintain agreements to support the community or showed disrespect to Evenki hunters and herders, then they use some informal strategies to assert their mastery of their territory.

Once the new manager came from Moscow and I came to take some food supplies to the mine. All the security personnel began to behave in a rude way to me, they inspected my personal belongings. Next time, it happened that I was walking near the beautiful lake with my reindeer and I noticed that the head of the gold mine and some others were having a picnic with vodka after fishing. I approached them and asked in a strict way: "Why are you making a mess here on my land? Please take everything with you." (FM: 2016)

Community leaders told me that sometimes they would close the road for those who travelled to the gold mine: "We started to ask gold miners for a pass because they are also asking for our passes" (FM: 2016). Indeed, the small reindeer herd, which is led by the experienced and skilled brigadier Grigoriy Kurbaltunov-Grinya, is always kept very close to the gold mine - it was the most remote reindeer herding brigade from Tyanya. To reach that camp, located on the Evenokit river, we travelled $200 \mathrm{~km}$ up the river through very difficult river conditions and then for two further days by all-terrain vehicle crossing rivers and mountain ridges.

To understand this situation, it is also worth mentioning that nearby lies the Charouda resource reserve (zakaznik) (13,720 square kilometers) established in 1997 under the initiative of the WWF. On one hand the reserve was part of clan territory used for reindeer herding; on another hand, it was prohibited to hunt and fish there. Hence, relations with the reserve gamekeeper were also complicated due to his good relations with gold miners. As usual, these tensions were expressed daily when Evenki travelled to their southern territories. At these times members of the clan community 
were stopped and rifles were frequently confiscated by the gamekeeper, who made it very difficult for people to get their rifles back. In return Evenki were enthusiastically involved in asking for the removal of the gamekeeper from his duty. To understand this situation better, it is important to know that mobility for most Evenki is a main driving force in their lives without this ability they cannot master territory or live as herders. Most activities in the camps are linked to movement for a wide variety of purposes, not just herding. Movement entails a wide variety of activities prior to actually leaving: the fixing of footwear, production and fixing of sleds, saddles and skis and more. People should be ready to move right away if an animal is being hunted and if it needs to be transported or a wolf pack is located nearby. Reindeer herding in itself requires constant movement, while the most important days and festivals that structure life are also associated with human and animal movements. Finally, people constantly move just to inspect their living environment as the places are also constantly shifting with the seasons. Any kind of official establishment of a territory includes the recognition of borders and the fixing of posts and cordons. The establishment of territories usually requires identification documents, rifle documents, permissions and a search of the herders' goods. Such official obstacles to free movement are viewed as the main challenge for herders.

The presence of reindeer herding close to the mines serves as a buffer for gold miners and as a way for herders to remind miners who is master of the territory. All hunting activities by miners or any 'free-ride' hunting or fishing in the area is monitored by reindeer herders. When this happens the leading reindeer herders come into contact with the intruders, reminding them of their control of the land and thus keeping exchanges between miners and herders in balance. Today, Neryungri Metallic provides food, gasoline and even gave an all-terrain caterpillar vehicle to the clan community. The vehicle helps the reindeer herders keep track of herds that are located at a distance from the village. Helicopters owned by the gold mining company are used in summer to deliver supplies to camps, count reindeer, bring a veterinarian if needed, and to hunt wolves. The gasoline provided by the mine is used to run generators in the camps as well as to drive snowmobiles in winter when different reindeer herders visit the village. Recently, the gold mining company planned to expand its activities and build a new ore mine with the aim of mining up to 6.8 tons of gold per year. Publicly Arsentiy acknowledged the success of cooperating with the Neryungri Metallic company as they have renewed agreements that ensure mutual understanding (FM: 2017). The mine paid local inhabitants about 3.5 million roubles as compensation for the use of their land in 2012.

\section{CASE 2: REINDEER HERDING NEAR THE BAM IN KALAR DISTRICT (ZABAIKAL'IA REGION)}

It would be impossible to understand the success of the Gavan reindeer herding community (in Kalar district of the Zabaikal Region) without mentioning the stubborn and hardworking head of the extended family Spiridon Gabyshev (Photo 2). Spiridon is the owner of the largest herd (up to 2,000 reindeer) in the South East Siberian taiga. His wife works as a schoolteacher and they have grandchildren in the Evenki village of Chapo Ologo. Some of their sons and grandchildren are involved in taiga reindeer herding and 
hunting. In 2017 Spiridon was 58 years old, the same age as his former classmate Arsentiy Nikolayev, and he moved constantly between taiga and village. After the collapse of the Soviet system both these charismatic leaders had the same ambition: to sustain liveable reindeer herding in their neighbouring districts. While both of them were the first to establish clan communities, they relied on different philosophies of how herding should be organised and sustained. While Arsentiy mainly relied on the efforts of the whole community including the accumulation and distribution of all administrative, economic and political interests among Evenki villagers, Spiridon refers to himself as an edinolichnik (single private owner). His strategy has been to rely only on his family members, effort and skills in the taiga, while at the same time being fond of using all available infrastructure and resources in his area as well as in villages and cities. The region also underwent the most intensive industrialisation in East Siberia during Soviet times.

Spiridon was born in the taiga near the Chara river, located in northern part of the Zabaikal Region. His parents were skilful reindeer herders and hunters. After collectivisation they were moved to Olekma region in the Sakha Republic and worked on a collective farm in Tyanya village. As a child Spiridon spent most of his time in the taiga learning hunting and herding skills and dropping out of school in the sixth grade, while his classmate, Arsentiy, continued his education, receiving a university diploma. At the age of 13 Spiridon started to work on a collective farm as a part-time reindeer porter (kayur) leading six cargo reindeer with his father who also worked for survey expeditions and took part in the construction of the longest northernmost railway, the BAM. The kayur work was well paid at the time. Collective farms had thousands of reindeer and the farms received about $70 \%$ of their income from cargo reindeer used in the construction of the railway. Indeed,

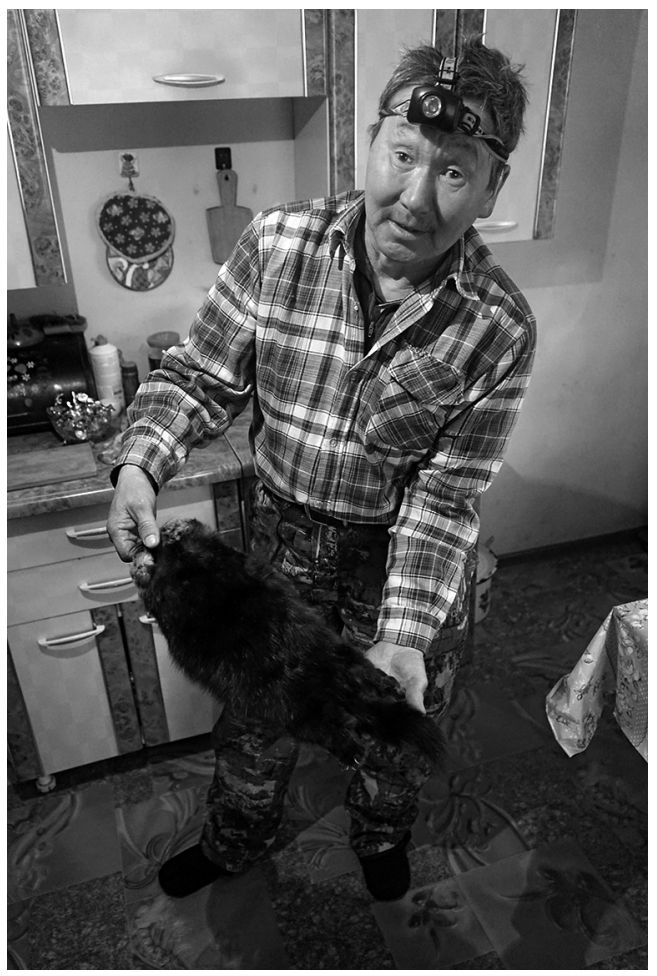

Photo 2. Spiridon Gabyshev showing his sable fur harvest. Photo by the author. the region was famous as home to a large number of domestic reindeer with herds reaching up to 9,000 head. As local Evenki remembered, there were many Evenki families with reindeer living in the region during the construction of the railway construction (FM: 2017). Spiridon served as kayur for 10 years (from 1974 to1984). In the process, he became a leading herder at the state collective farm in Kalar region in 1984. He settled with his family in the Evenki village of Chapo Ologo. Furthermore, Spiridon became a very successful hunter of fur animals while also fulfilling collective farm plans to hunt game animals in order to supply food to the BAM builders. If any reindeer herding brigade was in crisis, Spiridon was sent to 
resolve the issue. During this period he was successful in enlarging the herd and at the same time was recognised as a champion hunter.

The railway itself had a huge influence on the region and on Evenki communities in Kalar district. It was built as a state attempt to acquire the massive amounts of rich resources in East Siberia and to transport extracted resources to industrial plants. It was also intended to transport large numbers of people for the newly built cities and to work in the factories that processed extracted materials. Strong soviet propaganda based on the ideology of modernisation, the romanticism of conquering nature, and Soviet heroism attracted many people who wanted high salaries and material benefits (Povoroznyuk 2017; Schweitzer et al. 2017). Almost all of this multinational migration came from the republics of the former Soviet Union and were referred to as bamovtsy (BAM builders). They became the largest population in Siberia and have a specific socioeconomic identity. Indeed, the construction and intense industrialisation and urbanisation of the region brought massive problems to the local environment including pollution, forest devastation, overhunting and overfishing. The traditional Evenki migratory routes were also disrupted by the railway and caused the collective farms large reindeer losses. Soon, with the collapse of the Soviet Union, the image of BAM builders became devalued, while the railway project itself was criticised for being too expensive. While many BAM workers left the region, the remainder became actively engaged in poaching, black market trade and the search for anything that had a monetary value for trade. In addition to hunting wild animals they started to shoot domestic reindeer. The infrastructure and access to gasoline helped provide an easy influx of bad quality alcohol as well as increase bamovtsy access to remote taiga areas where they searched for opportunities for subsistence and trade. Today, with the re-intensification of resource exploration efforts, the BAM is continuously used as the main transporting line for various resources such as timber, coal, minerals, oil or various metal ores such as gold, copper, silver and various rare metals. The BAM is still used to transport people into and out of the area and there is a growing resource extraction industry in the region that has attracted large numbers of shift workers, called vakhtoviki.

Spiridon is not fascinated by the communist times, which according to him "spoiled the Evenki" (FM: 2017), nor with modernisation, which has devastated the environment and put an end to nomadic reindeer herding in the region. He is also not happy with the market economy, which brought many traders (whom he calls pejoratively baryga'reseller of stolen goods') aiming to buy furs and other goods cheaply and paying with poor quality vodka in return. He believes that the post-Soviet era brought nothing but power relations with resource exploiters and newcomers (priyezzhiye) who benefit from the hardship that the Evenki suffer. After the tragic deaths of a large number of young Evenki who lived in a few small villages, Spiridon also has a very negative view of drinking alcohol and often declares that he has never tried this kind of poison.

For Spiridon, as for the most Evenki, the BAM became a kind of swear word meaning industrial intrusion into the most successful pastures of wild and domestic animals in Soviet years. He also referred to newcomers as populations "without a head" and without understanding of the "life order and ethics of the taiga" (FM: 2017). According to Spiridon, "Even though the person has profitable work or a shop, they still travel with good vehicles and rifles with optical sights to slaughter many wild animals to trade in the market" (FM: 2017). This is seen by him not only as poaching, but also as 
depriving Evenki of their old way of life. He outlines this in the following way: "Everyone has to live his own life, one way he should go for digging a garden, while I will go for hunting. I know how to do this." (FM: 2017)

With the collapse of collective farms, Spiridon became owner of 15 reindeer and his father and mother received around 30 reindeer. Soon he was in charge of a private herd of about 50 reindeer. The 1990s and the collapse of infrastructure was, as he recalls, one of the hardest times in his life. He had to exchange hunted meat for various supplies, yet despite this it was very difficult to provide adequate food to feed his family, which consisted of five small children. His self-reliance on mobile hunting with his well-trained reindeer herd allowed him to access territories that few others could. This ultimately also provided him with an important means to earn a cash income. He became involved in tanning furs and producing caps, securing cash incomes from large local markets. With this income he used to buy reindeer calves, which were cheaper than adult reindeer, and so enlarged his herd. In 2001, he already had up to 200 reindeer and registered the first clan community in the region. Initially he aimed to keep his reindeer further from the industrial areas and therefore he grazed the herd in the area of Olonokon and Evenokit in Yakutia. Some Evenki reindeer herders from Tyanya village also helped him. Many reindeer herders who received small herds from the collectivisation period in Kalar district did not manage to continue reindeer herding in the taiga and killed their reindeer for food or cash. Spiridon, in contrast, increased his herd, also buying reindeer from herds located in the villages of Tyanya (Sakha Republic), Ust' Nyukzha (Amur) and Nichatka (Irkutsk). Indeed, Kadar ridge with its rich and wide valleys serves as an artificial corral for reindeer herding. In the highlands reindeer are only attacked a little by mosquitoes during the summer, while also being well protected from predators since herders can guard and watch the narrow passages to the river basins.

Spiridon also got a car park with an all-terrain tank, two all-terrain vehicles including a luxurious Lexus, six snowmobiles (three of them Yamaha) as well as a large cargo car. In other words, he displayed all the features of being well adapted to local infrastructure opportunities and did not hesitate to try new activities, such as being open to tourists visiting his reindeer herding camps, which also brought him an income. Recently, he has helped convince the administration of Kalar district to agree with gold miners on helicopter flights for wolf hunting and his clan community acquired special flying equipment to explore areas and, in this way, control predators.

Spiridon also passed his knowledge and skills on to his three sons and grandsons boasting that every son catches up to 100 sable in a season. Two reindeer herds are mainly taken care of by two of his sons and their children, who spend most of their time in the spectacular mountainous taiga of Zabaikal County. One herd is owned by the oldest son, Losha, who recently established a separate indigenous clan community called Metakat. The middle son will receive another part of the herd and will work to increase it. The same dedication to life with reindeer in the taiga is also passed to one of his grandsons who did not stay at school long and is now an active reindeer herder, committing his life to the taiga. When based at Chapo Ologo village, Spiridon constantly attends his reindeer herds using his ATV, presented to him by gold miners. He also supported his relatives based in Ust' Nyukzha with reindeer, giving 30 head in exchange for their help in herding. Spiridon was a skilful person not only in taiga economies but also in being able to organise support for reindeer herding in the offices of the 
Zabaikal Region local government. While the administration constrains the movement of wild and domestic animals, it is obvious that BAM infrastructure also provides local reindeer herders with some opportunities to transport goods to far away cities. Indeed, many reindeer herders in the Kalar region used the BAM and various train stations scattered in the area to go short distances, commuting between different indigenous communities or reindeer herders' camps beside the railway as well as administrative centres, or visit family members in other villages. Reindeer herders transport taiga goods, tools and supplies and reach distant pastures by train. The meat and fur of wild reindeer can be easily transported and traded by train. Herder leaders and villagers can also easily attend any political or cultural event on time.

While talking about his personal success, Spiridon emphasised that he was never fond of education, but he knows how to count money well. He explains his worldview in the following way: "The real Evenki lifestyle and calling is reindeer herding and hunting in the taiga, which can give you everything including self-sufficiency and wealth, while education does not give any value (netu tolka ot ucheby)" (FM: 2017). When saying this Spiridon points to his classmates who spent long years studying in universities, but now have no jobs. He also adds that it was enough for him to learn how to sell meat as well as how to trade reindeer parts and furs in order to receive a financial reward. Indeed, the large reindeer herd also provides his whole extended family with important cash income. They earn additional income from drying the velvet antlers (panty) to be traded in Omsk as well as the sable fur harvest that is traded by Spiridon at the Irkutsk auctions. He explains:

I like to go the straight way, I cannot invent cheating (pridumovat' svyakuyu khuynyu). I sell bear paws to traders going to China and I am waiting for good traders who sell kamus [valuable reindeer or moose leg fur] in Irkutsk Bodaibo. In Nyukzha baryga [negative nickname for traders] buy kamus for 300 roubles with vodka, then Evenki there get drunk and give everything away. Here, I sell for 600 roubles; they cannot cheat me, and they buy more than 650 kamus from me every year. ${ }^{3}$ (FM: 2017)

As Spiridon says reindeer satisfy all his economic and emotional needs: he acquired a new and spacious house in Ikab'ya village near the railway as well as maintaining a house in Chapo Ologo village. He said that reindeer herding was a path that he must follow with pride and dignity (FM: 2017).

At the same time, Spiridon is only slightly involved in indigenous Evenki activism and has a critical view of representations of Evenki who do not own reindeer. Nor is he an active member of the village community, which is, year by year, growing smaller. The school was recently closed, and many young people went to large cities and villages that can be easily accessed by train or paved roads from Chapo Ologo village. Spiridon's relations with the regional administration and state institutions such as the forestry department has never been simple. Firstly, he could hardly have legal control of territories for reindeer herding and often used to graze reindeer in his hunting territories. In 2010, the conflict between Spiridon and the local administration was so heated that he registered the herd in another district, Tungiro-Olekma, even though he herds the reindeer and lives in his hunting territory in the Kalar district of Zabaikal County. There were a few years when he refused to take part in reindeer herders' day festivals 
and reindeer races. In such instances Kalar district lost its main representative. Indeed, he is the one usually chosen by the administration and journalists to represent the reindeer herders for the media. Spiridon understands that the reindeer and his indigeneity play an important role in representations of the region in the context of many important plans, such as developing tourism along the Kadar mountain ridge and establishing a national park, as well as continuing intensive resource exploration. Journalists write about and video him when he brings his reindeer to the festivals in Chita or to reindeer herding day in Tungiro-Olekma district or near Old Chara village in Kalar district. This provides him both social prestige in the region and extra cash income. He also used to declare that state institutions were willing to close his clan community. He accused officials of refusing to confirm reindeer herding territory. He even refused to sign papers in order to receive state support for reindeer herding.

Nevertheless, Spiridon did not hesitate to be an inconvenient person by challenging ministers and governors based in Zabaikal's centre, Chita. The Evenki believe that the administration prefers to lend the land through auctions to city entrepreneurs who are running hunting enterprises. Furthermore, he raises important issues publicly, for example how the administration gives priority to the industrial activities in the region rather than reindeer herders. Indeed, after 2000 there was a modernisation program initiated to create good access to the railway. Soon new coal mines on the Apsan river will be opened and there is a major plan to extract rare metals such as uranium in Chineya and to reopen an old copper mine in Udokan. The intensification of resource extraction and development of infrastructure cause a large number of Evenki community concerns in the region centred on their economic life and identity, both of which are linked to land use and reindeer herding. Ecological concerns were also voiced in order to establish a large protected area (zakaznik) with a large administration and gamekeeper office based in Chara. While understanding that there is a need for the role of zakaznik, and there is hope for a peaceful shelter for reindeer herding, many Evenki also raise concerns about wolves and how they could live in strictly protected areas of zakaznik.

Spiridon's sustained efforts ensured him regular donations for each reindeer of up to 700 roubles every year. He was also given hunting licenses provided via the association of indigenous people that he could sell to other people. In 2017, he received licensees for 112 wild reindeer, 10 moose, 3 elk; he also sold some unused licenses. All Evenki are eligible to hunt year-round without licenses for their own consumption. Nevertheless, his successes do not guarantee him a territory for reindeer herding. For many years he did not manage to secure one legally, and so far, after a long and expensive procedure of measurement, it is still not registered. He keeps repeating:

I do have reindeer, but I do not have land for them, so I am constantly challenged by anybody who visits the taiga and shoots reindeer. If I had the right to reindeer herding land, I could protect it from poachers and demand that some roads in the area should be closed to limit access. (FM: 2017)

Indeed, Spiridon also said that his presence in the area of Amudisy or in Charouda (Yakutia), at least in the past, was also a guarantee for the presence of an ecological balance of fish, wild animals and so on. While living in Charouda he even served as gamekeeper and managed to confiscate rifles. Even today, Spiridon says that some city based hunters were not happy with him and wrote a petition saying that he did not 
allow them to hunt, fish or travel with a car around his reindeer herds. Even the right to lease the land from the state can become an obstacle as ownership of 600,000 hectares of highlands in Amudisy, which he needs for his herd, might cost around 2-3 million roubles every year for him.

\section{CONCLUSIONS}

Based on examples of two Evenki communities in the Zabaikal and Taimyr regions, Anderson (2006a) argued that after the collapse of the Soviet Union, Evenki reindeer herding continued in an 'autarkic form' that he described as taking advantage of the opportunities afforded by the state and global economy. Though reindeer numbers diminished dramatically, nevertheless, he suggests that it could not be referred to as a crisis, since the changing numbers of reindeer had not changed the way that humans relate to reindeer. Anderson (2006a; 2006b) shows how Evenki herders actively and successfully adapted to the post-industrial landscape and opportunistically made use of the new "post-Soviet social space". For Anderson, a successful post-Soviet reindeer herding life relies on the best use of places where borders between licensing regimes are the weakest and where herders need not spend much time and effort connecting with sedentary centres of power. However, as my recent ethnographic research in different regions suggests, almost 25 years after the collapse of the Soviet collective farms such clan communities as Boiun failed to master reindeer herding and nomadic lifeways. The same fate came to many other middle-sized reindeer herding groups in the southern part of the Sakha Republic, Buryatia Republic, Khabarovsk Region and Amur Region. Their 'autarkic' organisation of lifeways became their weakness because they lacked sustainability.

Based on the examples of two successful Evenki reindeer herding clan communities I argued that the hunting and herding success in the current socioeconomic and ecological environment is based not only on reindeer herding knowledge and skill, but also on adaptive clan community management and the persistency of charismatic and somehow well-connected leaders. Such success is based on their ability to relate to different agents of power in local administrations, large cities and governments. Such communities also rely on large reindeer herds and therefore high prestige and aim to manage large territories, gaining economic benefits from sustainable slaughtering and meat, state subsidies for each 'head', hunting fur animals and the support of the mines. Finally, such reindeer herding relies on the ability to unite reindeer herders and their families around subsistence in taiga tasks combining reindeer herding with hunting. It also relies on strong self-representations in different types of traditional cultural expressions such as crafts, stage arts, games and festivals. However, most charismatic leaders would consider the continuation of subsistence practices in the taiga an increasingly complicated task as there can be few young people skilful, knowledgeable and motivated enough to take care of reindeer and live a nomadic life. Hence, owning large or middle-sized reindeer herds varying from 100 to 1,000 reindeer is a constant challenge in the suboreal taiga for most successful clan communities, since remote taiga locations are well suited not only to reindeer herding, but also to predators including energy companies. Some Russian scientists state that reindeer herding has lost its economic 
role in terms of meat production for most indigenous communities in southern Sakha and therefore such herding is important only as cultural and social capital (see Klokov 2016). I would argue that the reindeer still remains the main source of wealth for both tangible and intangible reasons. Reindeer herding remains the main guarantee that the clan community, through their charismatic leaders, will keep and control large territories. Reindeer herding also serves to mobilise the whole community with moral and cultural tools that provide a purpose to their lives through their relationship with the reindeer and with the land.

For many reindeer herding families living far from city centres the issues of having limited access to financial resources, limited access to large territories necessary for a nomadic way of life, the rise in the numbers of predators, and the expansion of mining territories become the crucial reasons for losing reindeer and consequently not just a subsistence practice but a way of life and an identity that explains who they are. Fighting predators became impossible without great efforts from the wider community to actively hunt these predators, build corrals for reindeer and get miners to lend their helicopters or gasoline to fight wolves. The success of reindeer herding depends on abilities to negotiate the financial returns from mining and ensure stable use of suitable herding territory. The expansion of various kinds of industry in the remote areas causes ecological damage and also territorial constraints on herding. However, various and sometimes exhaustive tension with mining companies also helped leaders build communities around reindeer herding. Leaders also promoted political activism and local cultural practices, with the aim of becoming more publicly visible in Russia and to inspire the Soviet public to participate in celebrations and value the shamanic rituals of reindeer herders. The presence of industrial agents in the area is both a potential danger, threatening to destroy liveable environments as well as a source of financial support. Hence, such dynamics of interaction with various agents also serves to mobilise communities and their spatial and temporal strategies embracing territorial claims, economic benefits and cultural expressions.

\section{NOTES}

1 Already in the time of the Tsar Evenki actively used strychnine to poison wolves. Under pressure from international environmental organisations, the use of Barium was prohibited by the Russian state in 2005.

2 Usually the number of reindeer can fluctuate significantly, but it is always a strategy to declare a larger number of animals even when part of herd was lost due to attacks of predators since state dotation is paid to clan communities per head.

3 The head of the association of indigenous people in Zabaikal'ia, Inna Ferko, said that many Evenki hunters in Kalar do not have a right to have a gun because they do not have a house to keep it in, or that these Evenki have reindeer but are unable to administrate the communities' tasks (FM: 2017). It is often the case that local Russians provide them with guns and administrative support and take a large part of their fur harvest. Such people are called as Tungusyatniki (Tungus is an old ethnonym for Evenki). 


\section{SOURCES}

FM = Author's fieldwork materials (field notes audio recordings and visual material) from 20162017. Materials are kept in the author's possession.

\section{REFERENCES}

Anderson, David. 2006a. Is Siberian Reindeer Herding in Crisis? Living with Reindeer Fifteen Years after the End of State Socialism. - Nomadic Peoples 10 (2): 87-104. DOI: https://doi. org/10.3167/np.2006.100206.

Anderson, David. 2006b. Dwellings, Storage and Summer Site Structure among Siberian Orochen-Evenkis: Hunter-Gatherer Vernacular Architecture under Post-Socialist Conditions. Norwegian Archeological Review 39 (1): 1-26. DOI: https://doi.org/10.1080/00293650600703894.

Anderson, David. 2012. Shamanistic Revival in a Post-Socialist Landscape: Luck and Ritual among Zabaikal'e Orochen-Evenkis. - Landscape and Culture in the Siberian North, edited by Peter Jordan. London: University College London Press, 71-95.

Brandišauskas, Donatas. 2017a. Leaving Footprints in the Taiga: Luck, Rituals and Ambivalence among Orochen Reindeer Herders and Hunters in Zabaikal'ia, East Siberia. Oxford, New York, NY: Berghahn Press. DOI: https://doi.org/10.2307/j.ctvss40w3.

Brandišauskas, Donatas. 2017b. Staryye tekhnologii i sovremennoye izgotovleniye tayezhnogo snaryazheniya u evenkov Zabaykal'ya. - Izvestiya Laboratorii dreonikh tekhnologiy 13 (3): 44-57. [Брандишаускас, Донатас. 2017. Старые технологии и современное изготовление таежного снаряжения у эвенков Забайкалья. - Известия Ааборатории древних технологий 13 (3): 44-57.]

Belyanskaya, Marina. 2013. Olekminskiye evenki: statisticheskoye, istoriko-kul'turnoye issledovaniye. - Vestnik SFVU 10 (2): 165-170. [Белянская, Марина. 2013. Олекминские эвенки: статистическое, историко-культурное исследование. - Вестник СФВУ 10 (2): 165-170.]

Davydov, Vladimir. 2014. Issledovaniye otnosheniy cheloveka i olenya v Yuzhnoy Jakutii. - Materialy polevykh issledovaniy MAE RAN, edited by Ye. G. Fëdorova. Sankt-Peterburg.: MAE RAN, 95-117. [Давыдов, Владимир. 2014. Исследование отношений человека и оленя в Южной Якутии. - Материалы полевых исследований МАЭ РАН, отв. ред. Е. Г. Фёдорова. СанктПетербург: МАЭ РАН, 95-117.]

Davydov, Vladimir. 2018. Mobil'nost' kak reflektivnyy i kreativnyy protsess: Ispol'zovaniye infrastruktury evenkami Vostochnoy Sibiri. - Ural'skiy Istoricheskiy Vestnik 3 (60): 24-31. [Давыдов, Владимир. 2018. Мобильность как рефлективный и креативный процесс: Использование инфраструктуры эвенками Восточной Сибири. - Уральский Исторический Вестник 3 (60): 24-31.] DOI: https://doi.org/10.30759/1728-9718-2018-3(60)-24-30.

Humphrey, Caroline. 1999. Marx Went Away - But Karl Stayed Behind. Ann Arbor, MI: University of Michigan Press. DOI: https://doi.org/10.3998/mpub.11004.

Klokov, Konstantin K. 2016. Reindeer Herders' Communities of the Siberian Taiga in Changing Social Context. - Sibirica 15 (1): 81-101. DOI: https://doi.org/10.3167/sib.2016.150104.

Povoroznyuk, Olga. 2017. Social Dynamics and Sustainability of BAM Communities: Migration, Competition for Resources, and Intergroup Relations. - New Mobilities and Social Changes in Russia's Arctic Regions, edited by Marlene Laruelle. London: Routledge, 133-157.

Schweitzer, Peter; Olga Povoroznyuk and Sigrid Schiesser. 2017. Beyond Wilderness: Towards an Anthropology of Infrastructure and the Built Environment in the Russian North. - The Polar Journal 7 (1): 58-85. DOI: https://doi.org/10.1080/2154896X.2017.1334427. 